\title{
Effect of wound healing in gels containing tinctures of Alnus glutinosa $(L)$ leaves
}

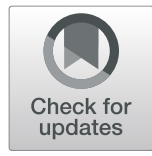

Volha Mushkina(D)

\begin{abstract}
Background: Alnus glutinosa $(L)$ is a widespread medicinal plant on the territory of the Republic of Belarus. Alnus glutinosa $(L)$ leaves tincture has an anti-inflammatory effect on the diseases of the throat, intestines, in rheumatism and gout. Water extracts from collective fruit, leaves and bark are used for gargling in stomatitis and gum bleeding. The purpose of the research was to establish wound healing activity of gels based on alcohol extracts from Alnus glutinosa ( $L$ ) leaves on the model of a surface full flap skin wound on laboratory animals.

Methods: Regenerating action of new drugs (gels) based on tinctures of Alnus glutinosa (L) leaves was studied on a model of planar full-layer skin wound in laboratory animals. Wounds were treated daily with gels applied to complete healing. The wound area was measured planometrically to assess the effectiveness of drugs and then the percentage of area reduction was calculated. Regenerative action of the gels developed was compared to widely used in medical practice 4\% Dexpanthenol Gel and Reparef-2 Ointment. $15 \mathrm{~g}$ of Reparef-2 Ointment contains 1200 $\mathrm{mg}$ of bien and $75 \mathrm{mg}$ of dioxidine.

Results: Wound healing activity of gels containing tinctures of Alnus glutinosa (L) leaves based on 30\% and 60\% alcohol as to the rate of healing and the area of wounds epithelialization has been proved. Wound area treated with the gel based on Alnus glutinosa (L) extract containing 60\% alcohol on day 13 of the experiment decreased by $95.59 \% \pm 0.9 \%$ ( $p \leq 0.05)$; based on the tincture containing 30\% alcohol - by $92.93 \% \pm 1.11 \%$. Medicinal preparations with proved wound healing activity were compared: Reparef-2 Ointment (reduction percentage of wound area on day 13 of the experiment made $92.24 \% \pm 2.21 \%$ ) and Dexpanthenol Gel (reduction percentage of wound area on day 13 of the experiment made $83.09 \% \pm 3.41 \%$ ).

Compared with the control group the gel based on 60\% tincture of Alnus glutinosa ( $L$ ) leaves showed a decrease in the epithelialization period by 29.5\%; based on 30\% tincture - by 24.6\%; Reparef-2 Ointment - by $23.6 \%$ and Dexpanthenol Gel - by $13.8 \%$.

Conclusions: The results of this study showed that the developed gels based on Alnus glutinosa (L) have a regenerating action and can be used to treat wound processes taking into account previously established antimicrobial activity.
\end{abstract}

Keywords: Alnus glutinosa (L), Wounds, Regenerating action, Gel

Correspondence: Olga7081@tut.by

Department of Organization of Pharmacy, Belarussian State Medical

University, Minsk, Belarus

Springer Open (c) The Author(s). 2021 Open Access This article is licensed under a Creative Commons Attribution 4.0 International License, which permits use, sharing, adaptation, distribution and reproduction in any medium or format, as long as you give appropriate credit to the original author(s) and the source, provide a link to the Creative Commons licence, and indicate if changes were made. The images or other third party material in this article are included in the article's Creative Commons licence, unless indicated otherwise in a credit line to the material. If material is not included in the article's Creative Commons licence and your intended use is not permitted by statutory regulation or exceeds the permitted use, you will need to obtain permission directly from the copyright holder. To view a copy of this licence, visit http://creativecommons.org/licenses/by/4.0/. 


\section{Introduction}

Alnus glutinosa ( $L$ ) Gaertn. is a deciduous tree up to 20$25 \mathrm{~m}$ high of the Birch family (Betulaceae). It is spread in the Western part of Asia, almost throughout Europe and in the Northern countries of Africa. Alnus glutinosa (L) grows on peat-bog and humic gley soils having high water cut running water and lives up to $80-100$ years. It is frost-resistant, relatively photophilous and requires moist and rich soils. It forms forests at foot slopes, in overflow lands and swampy lowlands $[1,2]$.

The leaves of Alnus glutinosa (L) contain flavonoid glycosides - hyperoside and quercetin, caffeic acid, chlorogenic and pyrocatechine acids, up to $20 \%$ protein, $6 \%$ fat, ascorbic acid and carotene. The chemical composition of collective fruit is presented by tannins, flavonoids, phenolcarboxylic acids and triterpenoids [3].

In medicine tinctures and infusions of Alnus glutinosa (L) collective fruit are used to treat acute and chronic enteritis, colitis, dysentery, colds, in gargling the throat and oral cavity. The drug Altan obtained from Alnus glutinosa ( $L$ ) fruit is used to treat gastric and duodenal ulcers, gastritis, gastroduodenitis [4]. The drug Altabor containing dry Alnus glutinosa (L) and Alnus incana (L.) collective fruit extract exerts an antiviral action on influenza viruses and herpes simplex.

Other types of this plant raw material are also used in traditional medicine: bark, leaves and aments. A decoction of fresh leaves and bark is used for gargling in stomatitis and ulemorrhagia $[5,6]$.

Alnus glutinosa ( $L$ ) leaves tinctures have expressed antimicrobial activity on gram-negative enterobacteria of the intestinal group (Escherichia coli) and have a slight effect on gram-positive microorganisms such as Staphylococcus aureus. In recent years the interest of scientists has been attracted to the antitumor activity obtained from bark, collective fruit and Alnus glutinousa (L) leaves. Bark and leaf extracts inhibit the growth of adenocarcinoma [7-9]. To prove the wound healing effect of Alnus glutinosa (L) leaves we used gels based on alcohol tinctures to treat a superficial full-bodied skin wound of laboratory animals.

\section{Materials and methods}

\section{Plant collection, preparation and extraction}

Fresh leaves of Alnus glutinosa (L) (IPNI Life Sciences Identifier (LSID) urn:lsid:ipni.org:names:30036759-2) [10] were collected from Minsk region of the Republic of Belarus in June, 2018. The collected plant samples were identified by Doctor of Biological Sciences Natalia Gurina, professor from Belarusian State Medical University. Voucher specimen has been deposited in Herbarium of the World Flora of the Central Botanical Garden of the National Academy of Sciences of Belarus with a number MSKH:16512 for further references.
They were dried at room temperature $\left(20-25^{\circ} \mathrm{C}\right)$ in well-ventilated rooms without direct sunlight.

\section{Preparation of plant extracts}

Dried leaves were crushed to rough powder. Two types of tinctures were prepared: using 30\% and 60\% ethyl alcohol. Extraction from the powder of Alnus glutinosa ( $L$ ) leaves was made at room temperature. Alnus glutinosa $(L)$ leaves were mixed with ethyl alcohol in a ratio of 1:5 and kept for 7 days stirring daily for $15 \mathrm{~min}$. Then it was filtered using filter paper.

For making the gel containing 30\% tincture, tylopur was used as a gelatinizing agent. $97.0 \mathrm{~g}$ of tincture was poured into an open-mouthed vessel and $3.0 \mathrm{~g}$ of tylopur was added through double layer cheesecloth by slow layering at constant and intensive mixing to ensure uniform gelling.

Water, EDTA, carbomer, macrogol, propylene glycol and diethanolamine were added to make $100 \mathrm{~g}$ of gel containing 60\% tincture from Alnus glutinosa (L) leaves. The content of tincture in the gel made $50 \%$.

$0,01 \mathrm{~g}$ of EDTA and $1 \mathrm{~g}$ of carbomer were added to 29 $\mathrm{ml}$ of water, mixed properly and left for $24 \mathrm{~h}$. After $24 \mathrm{~h}$ diethanolamine was added to $\mathrm{pH} 7$ (approximately 40 drops, control was made with a $\mathrm{pH}$-meter). Then $10 \mathrm{~g}$ of macrogol, $10 \mathrm{~g}$ of propylene glycol and $50 \mathrm{~g}$ of Alnus glutinosa $(L)$ leaves tincture based on $60 \%$ of ethyl alcohol were mixed, the resulting mixture was added to the gel and mixed thoroughly.

\section{Experimental animals}

White wistar rats of both sexes weighing 200-250 g were kept under standard conditions of temperature (20$22^{\circ} \mathrm{C}$ ), air humidity (45-50\%) and under natural illumination. Standard food for rodents and the required amount of water daily were provided. All studies were conducted in accordance with the ethical principles of the Convention for the Protection of Animals used in the experiment and for other scientific purposes adopted by the Council of Europe in 1986 [11].

The studies were conducted by the permission of the Biomedical Ethics Committee of Belarusian State Medical University, organized by the order No. 309 dated June 15, 2012, proceedings № 4 dated 09.01.2018.

\section{Wound healing activity}

Wound healing activity of Alnus glutinosa (L) leaf gels was studied on the model of a planar full-thickness cutaneous wound [12-15].

Round wounds with an area $100-150 \mathrm{~mm}^{2}$ were modeled on the animals under anesthesia. The skin with hypoderm was excised with surgical scissors on a shaved area of the back in nonsterile conditions. The wounds were left open and after $24 \mathrm{~h}$ treatment was started once 
a day till complete healing. Animals were divided into 5 groups of 6 animals per group. Group 1 - the control one (wounds were treated with $0.9 \% \mathrm{NaCl}$ solution), group 2 - wounds were treated with the gel containing tincture of Alnus glutinosa (L) leaves based on 30\% ethyl alcohol, group 3 - wounds were treated with Reparef-2 Ointment, group 4 - wounds were treated with the gel containing Alnus glutinosa ( $L$ ) leaves tincture based on $60 \%$ ethyl alcohol, group 5 - wounds were treated with Dexpanthenol.

Active ingredients of Reparef-2 Ointment are bien and hydroxymethylquinoxalindioxide (dioxidine) with excipients: essential oil of geranium, polysorbate, macrogol 1500, macrogol 400. Bien is a complex of ethyl esters of polyunsaturated fatty acids, stabilized with alphatocopherol acetate (vitamin E). It contains essential fatty acids - arachidonic (a precursor of prostaglandins and leukotrienes), oleic, linoleic and linolenic (vitamin F) ones.

Dexpanthenol Gel contains active substance dexpanthenol and excipients: 96\% of ethyl alcohol, glycerin, carbomer, dimethyl sulfoxide, povidone, benzalkonium chloride, diethanolamine, benzyl alcohol, purified water [16].

Starting from the second day of the experiment (the first day of measurement $-S_{1}$ ) formation the wounded area was planometrically measured daily. Transparent film onto which the wound was contoured with a marker was applied to the wound. Wound area calculation was made using linear graph paper.

To assess the effectiveness of drug regenerating properties the percentage of wound closure was calculated with the formula $(1)[13,17]$ :

$$
P W C=\frac{\left(S_{1}-S_{n}\right) \times 100}{S_{1}}
$$

PWC - percentage of wound closure; $S_{1}-$ the wounded area per day 1 of measurement; $S_{n}$ - the wounded area per day of measurement (days 2-13 of measurement) To find epithelization period, the day of the experiment, on which complete wound healing occurred, was recorded. Then the percentage of epithelization periods reduction $(\mathrm{X})$ of the experimental groups relating to the control group was calculated with the formula (2) [15]:

$$
\mathrm{X}=\frac{\mathrm{Nc}-\mathrm{N} \times 100}{\mathrm{Nc}}
$$

Nc - day of complete healing in the control group and $\mathrm{N}$-day of complete healing in the experimental groups.

\section{Statistical analysis}

Statistical analysis of the results obtained was made using "Statistica 10.0" in compliance with general recommendations for biological research. Distribution-free methods of research that met the criteria of the experiment conducted were used in the analysis (a small sample group $n \leq 6$, the standard distribution kind was unknown and the values were considered significant at $p<0.05)$.

\section{Results}

\section{Wound contraction}

The percentage of wound contraction (PWC) was compared in all groups on day 5, 9 and 13, the results are presented in Figs. 1, 2 and 3.

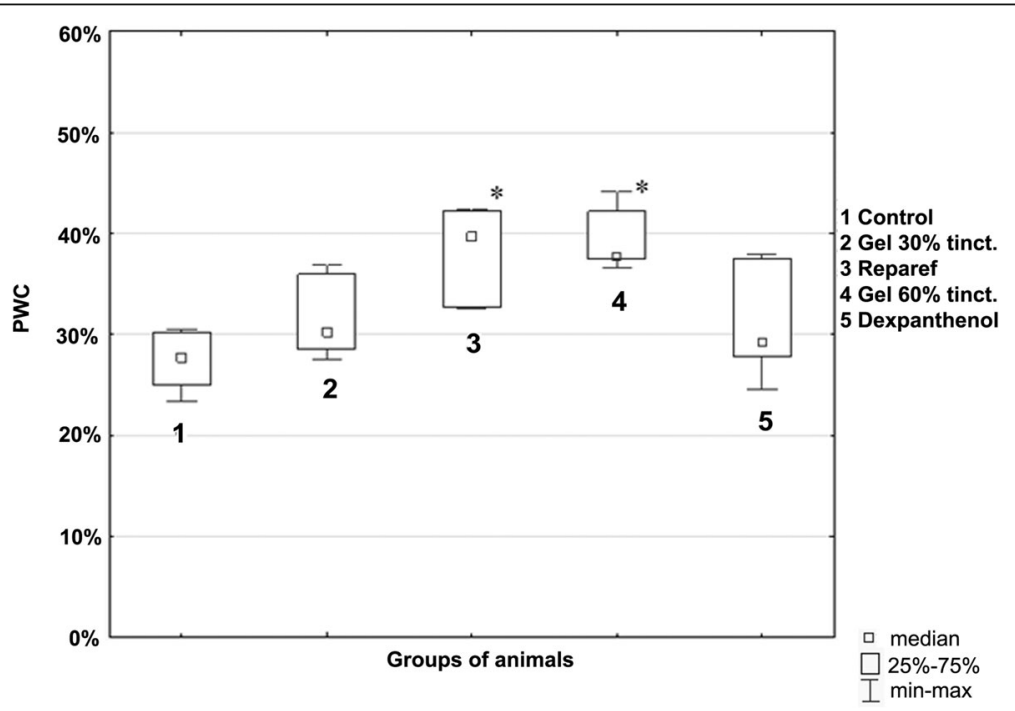

Fig. 1 Percentage of wound closure per day 5. ${ }^{*} p<0.05$ vs control group 


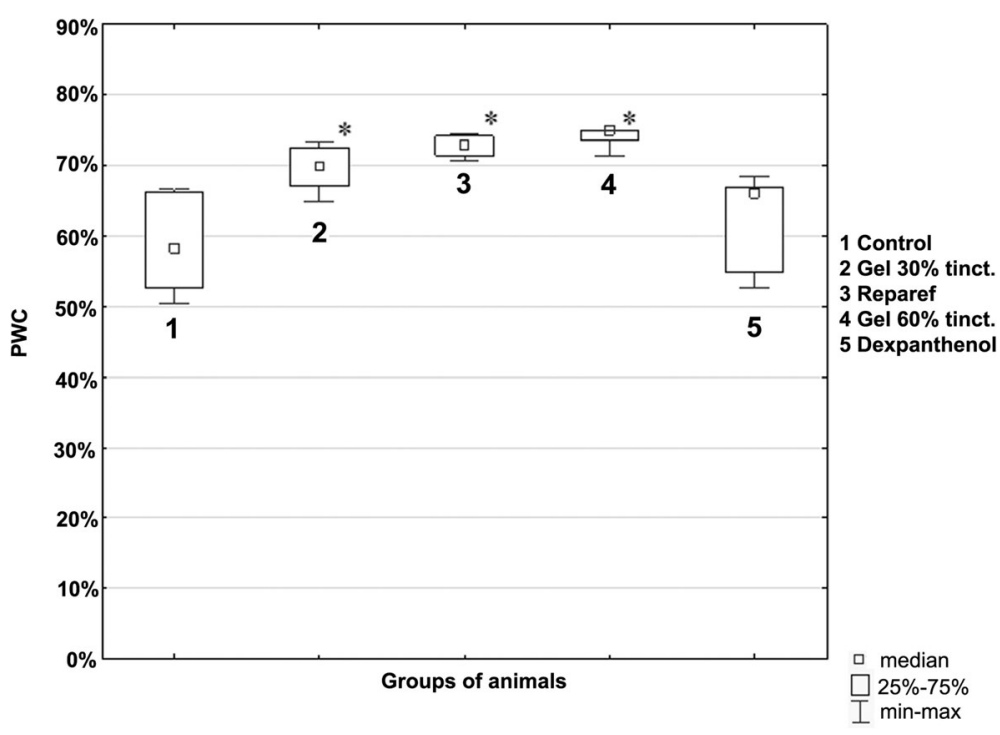

Fig. 2 Percentage of wound closure per day 9. ${ }^{*} p<0.05$ vs control group

The PWC index treated with the gel containing 60\% tincture on day 5 had the value of $39.32 \pm 2.47 \%$ which significantly differed from the PWC index in the control group of animals $(27.39 \pm 2.46 \%)(p<0.05)$ as well as it differed from the PWC index $-31.08 \pm 4.02 \%$ in the group of animals where the wounds were treated with Dexpanthenol Gel. PWC of wounds in Group 5 of animals didn't statistically differ from the control group $(\mathrm{p}>0,05)$ (Fig. 1).

PWC treated with the gel containing 30\% tincture of Alnus glutinosa ( $L$ ) leaves made $32.71 \pm 5.50 \%$ that statistically did not differ from the control group $(p>0.05)$.
PWC in group 3 of animals where wounds were treated with Reparef-2 Ointment had the value of $38.17 \pm 3.88 \%$ (Fig. 1 ).

PWC on day 9 under the action of the gel containing $60 \%$ tincture was $74.12 \pm 1.18 \%$; under the action of the gel containing $30 \%$ tincture $-69.62 \pm 2.77 \%$; under the action of Reparef-2 Ointment - $72.8 \pm 1.16 \%$; under the action of Dexpanthenol Gel - $62.51 \pm 5.13 \%$, in the control group $-58.70 \pm 5.46 \%$. PWC in the groups of animals treated with the gels containing tinctures from Alnus glutinosa (L) leaves statistically significantly differed from PWC in the control group $(p<0.05)$ and the

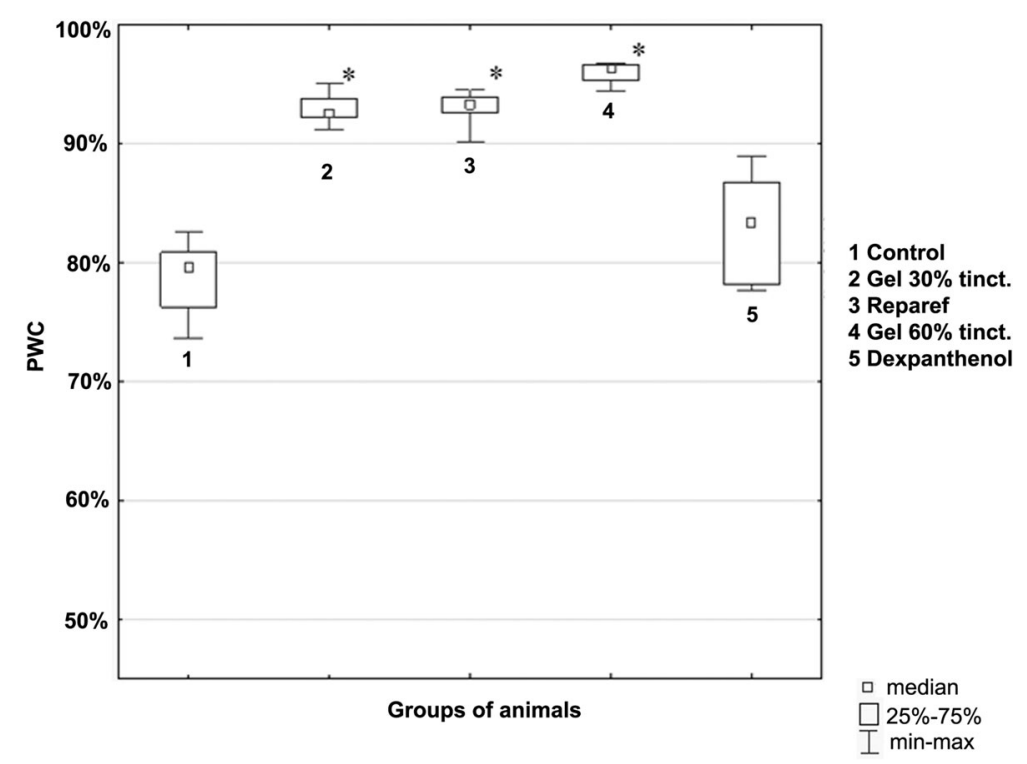

Fig. 3 Percentage of wound closure per day 13. ${ }^{*} p<0.05$ vs control group 
PWC treated with Dexpanthenol Gel $(\mathrm{p}<0.05)$. PWC of wounds on day 9 in Group 5 of animals didn't statistically differ from the control group ( $\mathrm{p}>0.05$ ) (Fig. 2).

PWC on day 13 of the experiment under the action of the gel containing $60 \%$ tincture was $95.59 \pm 0.9 \%$; under the action of the gel containing 30\% tincture $-92.93 \pm$ $1.11 \%$; under the action of Reparef-2 Ointment - $92.24 \pm 2.21 \%$; under the action of Dexpanthenol Gel $83.09 \pm 3.41 \%$; in the control group $-78.78 \pm 2.65 \%$. PWC in the groups of animals treated with the gels containing tinctures from Alnus glutinosa (L) leaves and Reparef-2 Ointment statistically significantly differed $(p<0.05)$ from PWC in the control group and PWC treated with Dexpanthenol Gel (Fig. 3).

\section{Epithelialization period}

Epithelialization period of the wounds treated with the gel containing $60 \%$ tincture of Alnus glutinosa ( $L$ ) leaves on the average was 14.3 days; treated with the gel containing 30\% tincture of Alnus glutinosa ( $L$ ) leaves - 15.3 days, in the control group - 20.3 days. The rate of wound epithelization in the groups of animals where plant gels were used was statistically different from the control group $(p<0.05)$ and the group of animals in which wounds were treated with Dexpanthenol Gel $(p<0.05)$.

Compared with the control group the gel based on $60 \%$ tincture of Alnus glutinosa ( $L$ ) leaves showed a reduction in the epithelization period by $29.5 \%$, based on $30 \%$ tincture - by $24.6 \%$, Reparef- 2 Ointment - by $23.6 \%$, Dexpanthenol Gel - by $13.8 \%$ (Table 1).

\section{Discussion}

According to the results above it was found that Alnus glutinosa $(L)$ leaves tincture-based gels had an expressed wound healing effect. But the gel, containing tincture based on $60 \%$ ethyl alcohol turned out more efficient than the gel containing tincture based on 30\% ethyl alcohol.

On day 5 only gel based on 60\% tincture of Alnus glutinosa $(L)$ leaves showed a pronounced wound healing effect. On day 5 the PWC index treated with the gel was significantly higher than PWC of the control group of animals $(p \leq 0.05)$ and PWC treated with Dexpanthenol gel $(\mathrm{p} \leq 0.05)$. PWC on day 5 treated with the gel containing 30\% tincture of Alnus glutinosa (L) leaves was slightly higher than in the control group but the differences did not reach statistical significance. There was no significant difference in wound healing activity between the gel based on 30\% tincture, Reparef - 2 Ointment and Dexpanthenol gel which indicates the compatibility of their therapeutic effects.

On day 9 and 13 of the experiment the area of wound healing under the action of gels based on tinctures from Alnus glutinosa ( $L$ ) leaves is significantly higher than in the control group of animals and in the group of animals in which the wounds were treated with Dexpanthenol.

Reduction percentage of the wound area treated with the gel containing Alnus glutinosa (L) leaves tincture based on $60 \%$ alcohol was statistically significantly different from the control group during the whole epithelialization period. On day 5 PWC was higher than in the control group by $11.93 \%(p<0.05)$, on day 9 - higher by $15.42 \%(p<0.05)$, on day 13 higher by $16.81 \%(p<0.05)$.

PWC of wounds applying the gel containing tincture based on 30\% alcohol exceeded the PWC of wounds in the control group by $10.92 \%$ on day 9 , and by $14.15 \%$ on day $13(p<0.05)$.

Medicinal plants show wound healing effects by different mechanisms, such as modulation in wound healing, reduction in bacterial count, improvement in collagen deposition, increase in fibroblasts and fibrocytes, etc. [18]. Alnus glutinosa ( $L$ ) leaves contain a unique polyphenolic complex including flavonoids, tannins, phenolic acids allowing to use them for the preparation of wound healing drugs [2, 19]. It has been previously stated that a polyphenolic complex of Alnus glutinosa (L) leaves extracts has antiinflammatory and antimicrobial effects $[8,20]$ and also contains antioxidants [19].

In the first phase of inflammation the target for flavonoids from Alnus glutinosa ( $L$ ) leaves is enzymes inducing the synthesis of active inflammatory inducers prostaglandins, thromboxanes, prostacyclins, leukotrienes and others.

Table 1 The period of complete healing in rats of different groups

\begin{tabular}{lll}
\hline The drug used for wound treatment & Recording date of full healing & Percent reduction of epithelialization periods \\
\hline $0.9 \% \mathrm{NaCl}$ & $20.3 \pm 0.9$ & \\
Gel based on 30\% tincture of European alder leaves & $15.3 \pm 0.7^{*}$ & 24.6 \\
Gel based on 60\% tincture of European alder leaves & $14.3 \pm 0.4^{*}$ & 29.5 \\
Reparef -2 Ointment & $15.5 \pm 0.7^{*}$ & 23.6 \\
Dexpanthenol Gel & $17.5 \pm 0.8^{*}$ & 13.8 \\
\hline
\end{tabular}

*- significantly different compared to the control group $p<0.05$

As observed from the table the gel based on $60 \%$ tincture of Alnus glutinosa $(L)$ leaves has the highest healing rate 
A malfunctioning antioxidant system causes increased oxidative stress, which damages proteins, nucleotides, lipid levels and slows down wound healing [21]. The presence of reactive oxygen species and microbes at the wound site has synergetic effects causing delay in healing [22]. Consequently, the antioxidants of Alnus glutinosa (L) alcohol extracts remove free radicals and enhance the proliferative properties of cells. Antimicrobial effect of biologically active substances of Alnus glutinosa ( $L$ ) also helps to accelerate the healing process.

Tannins from Alnus glutinosa (L) could promote cicatrisation of wounds through several cellular mechanisms such as promoting contraction of the wound, and increasing formation of capillary vessels and fibroblasts [23]. It can also decrease the permeability of capillaries in the wound and alleviate tissue edema and exudation resulting in rapid scab formation [24].

The use of the developed gels led to the reduction in the epithelialization period compared to the control group by 6 days (the gel containing tincture based on $60 \%$ alcohol) and by 5 days (the gel containing tincture based on $30 \%$ alcohol).

Thus, a preliminary study of the component composition and pharmacological activity of Alnus glutinosa (L) leaves extracts made it possible to predict the woundhealing effect of the gels based on them. The research results proved the pronounced wound-healing effect of the developed plant gels compared to the animals in the control group.

\section{Conclusion}

The gels based on alcohol extracts from Alnus glutinosa $(L)$ leaves have proved wound healing effect for the first time. These gels significantly reduce epithelization period compared to the effect of Dexpanthenol Gel and Reparef-2 Ointment. Thus, the developed gels can be used as a medicine for the treatment of skin wounds or in combination with modern wound healing medicines.

\section{Acknowledgements}

Not applicable.

Rights and permissions

Not applicable.

Additional information

Not applicable.

\section{Author's contributions}

Volha Mushkina searched relevant literature, selected, planned, designed and handled experiment with animals, processed the received data. The author read and approved the final manuscript.

\section{Funding}

No funding.

\section{Availability of data and materials}

The datasets used and analyzed during the current study are available from the corresponding author on reasonable request.

\section{Declarations}

Ethics approval and consent to participate

The studies were conducted by the permission of the Biomedical Ethics Committee of Belarusian State Medical University, organized by the order No. 309 dated June 15, 2012, proceedings № 4 dated 09.01.2018.

\section{Consent for publication}

Not applicable.

\section{Competing interests}

The author declares that he has no competing interest.

Received: 28 March 2020 Accepted: 30 June 2021

Published online: 09 July 2021

\section{References}

1. San-Miguel-Ayanz J., de Rigo D., Caudullo G., Houston Durrant T., Mauri A. Alnus glutinosa in Europe: distribution, habitat, usage and threats. In: European Atlas of Forest Tree Species. 2016 Available online: https://forest. jrc.ec.europa.eu/en/european-atlas/ Alnus glutinosa in Europe: distribution, habitat, usage and threats (Accessed 6 Jan. 2020).

2. Bykov VA. Atlas of medicinal plants of Russia. Moscow: VILAR; 2006.

3. Golovkin BN, Rudenskaya RN, Trofimova IA, Shreter Al. Biologicalzz active substances of plant origin: Moskva, Nauka; 2001.

4. Zuzuk BM, Kutsik RV, Radko OV, Kulagina MA, Serbln AG. White alder, speckled alder (Alnus incan (L.)), Moench. Analytical review. Provizor. 2007;9: 37-41.

5. $\quad$ Ilyina TA. Medicinal plants of Russia. Moskva: Eksmo; 2006.

6. Sushil Chandra Sati, Nitin Sati, and Sati O. P. Bioactive constituents and medicinal i mportance of genus Alnus. Pharmacogn Rev. 2011; 5(10): 174183. Available online: https://www.ncbi.n/m.nih.gov/pmc/articles/PMC3263 052/ (Accessed 12 Jan. 2020)

7. Xueyang Ren, Ting He, Yanli Chang, Yicheng Zhao, Xiaoyi Chen, Shaojuan Bai, Le Wang, Meng Shen and Gaimei She. The Genus Alnus, A Comprehensive Outline of Its Chemical Constituents and Biological Activities. Molecules. 2017; 22, 1383. Available online: https://europepmc. org/article/pmc/pmc6152317 (Accessed 12 Jan. 2020).

8. Mushkina O.V., Petrovich D.M., Gurina N.S., Generalov I.I. Antimicrobial activity of biologically active substances from the leaves of Alnus glutinosa L. Aktualnyie voprosyi sovremennoy meditsinyi i farmatsii: materialyi 59 itog. nauchno-prakticheskoy konferentsii studentov i molodyih uchenyih, Vitebsk. 2007; 218-220.

9. $\quad$ Altinyay Ç., Eryilmaz M., Yazgan A.N., Sever Yilmaz B., Altun M.L. Antimicrobial activity of some Alnus species. European Review for Medical and Pharmacological Sciences. 2015; 19: 4671-4674. Available online: https://www.researchgate.net/profile/Muejde_Eryilmaz/publication/2805634 94_Antimicrobial_Activity_of_Some_Alnus_Species/links/5696c7c408ae1c42 7903e33a.pdf (Accessed 22 Jan. 2020).

10. International Plant Name Index (IPNI). Available online: https://ipni.org/n/3 0036759-2 (Accessed 04 Jun. 2021).

11. European Convention for the Protection of Vertebrate Animals used for Experimental and Other Scientific Purposes. European Treaty Series - No. 123. Available online: https://rm.coe.int/168007a67b (Accessed 04 Jun. 2021).

12. Hemant Kumar Nagar, Amit Kumar Srivastava, Rajnish Srivastava, Madan Lal Kurmi, Harinarayan Singh Chandel and Mahendra Singh Ranawat. Pharmacological Investigation of the Wound Healing Activity of Cestrum nocturnum (L.) Ointment in Wistar Albino Rats. Journal of Pharmaceutics. 2016. Available online: https://www.hindawi.com/journals/jphar/2016/924 9040/ (Accessed 16 Jan. 2020).

13. Wubante Demilew, Getnet Mequanint Adinew, Seyfe Asrade Evaluation of the Wound Healing Activity of the Crude Extract of Leaves of Acanthus polystachyus Delile (Acanthaceae). Evidence-Based Complement. and Alternat. Med. 2018, 2047896. Available online: https://www.hindawi.com/ journals/ecam/2018/2047896/ (Accessed 12 Oct. 2019).

14. Bubenchikova V.N., Malyutina A.Yu., Novikova L.S., Grigoryan A.Yu., Zatolokina M.A., Zhilyaeva L.V. Wound healing activity of the gel based on dense extract of the herb Achyrophorus. Fundamental research. 2013; \# 81: 123-127. Available online: https://www.fundamental-research.ru/ru/a rticle/view?id=31884 (Accessed 12 Oct. 2019). 
15. Grabarskaya E.A., Danilevskaya N.V., Deltsov A.A., Pravda A.A. Studies of wound healing activity of the new multicomponent ointment. Rossiyskiy veterinarnyiy zhurnal. 2015; 3: 48-50. Available online: https://www.elibrary ru/contents.asp?id=34078758 (Accessed 12 Jan. 2020).

16. Instructions for the use of medicines. State Register of Medicines of the Republic of Belarus. Available online: https://www.rceth.by/Refbank/reestr_ lekarstvennih_sredstv/results (Accessed 20 June 2020).

17. Heidari M., Itani Rood B., Abdolghaffari Amir H., Rahimi R. Efficacy of topical application of standardized extract of Tragopogon graminifolius in the healing process of experimental burn wounds. J. of Traditional and Complementary Medicine. 2019; 9: 54-59. Available online: doi: 10.1016 / j. jtcme.2018.02.002 (Accessed 10 Jan . 2020).

18. Reza Farahpour Medicinal plants in wound healing Wound Heal Curr Perspect IntechOpen. 2019. Available online: https://www.intechopen.com/ books/wound-healing-current-perspectives /medicinal -plants-in-woundhealing (Accessed 30 March 2021).

19. Mushkina O.V., Gurina, N.S., Konopleva M.M., Bylka W., Matlawska I. Activity and total phenolic content of Alnus glutinosa and Alnus incana leaves. Acta scientiarum polonorum. Hortorum Cultus. 2013; 12(3): 3-11. Available online: http://www.hortorumcultus.actapol.net/volume12/issue3/abstract-3. html (Accessed 9 Jan . 2020).

20. Mushkina O.V., Gurin S.A. The effect of extracts from the leaves of Alnus incana and Alnus glutinosa on biochemical blood indices in generalized inflammation. Vesnik VSU. 2010; \#5: 45-48. Available online: https://lib.vsu. by/jspui/bitstream/123456789/5434/1/v10n5p45.pdf (Accessed 9 Jan . 2020).

21. Sharma P, Jha AB, Dubey RS, Pessarakli M. Reactive oxygen species, oxidative damage, and antioxidative defense mechanism in plants under stressful conditions. Journal of Botany. 2012;24:1-26. Available online: DOl: 10.1155 / 2012/217037 (Accessed 30 March 2021).

22. Arun M., Satish S., Anima P. Evaluation of wound healing, antioxidant and antimicrobial efficacy of Jasminum auriculatum Vahl. leaves. Avicenna Journal of Phytomedicine. 2016;6(3): 295-304. Available online: https://www. ncbi.nlm.nih.gov/pmc/articles/PMC4930536 (Accessed 22 Jan . 2020).

23. Fernandez O, Capdevila JZ, Dalla G, Melchor G: Efficacy of Rhizophora mangle aqueous bark extract in the healing of open surgical wounds. Fitoterapia. 2002, 73: 564-568. (0Available online: https://pubmed.ncbi.nlm. nih.gov/12490213/ (Accessed 30 March 2021).

24. Li K., Diao Y., Zhang H. et al. Tannin extracts from immature fruits of Terminalia chebula Fructus Retz. promote cutaneous wound healing in rats. BMC Complement Altern Med 11, 86 (2011). Available online: https://www. ncbi.nlm.nih.gov/pmc/articles/PMC3198757/ (Accessed 30 March 2021).

\section{Publisher's Note}

Springer Nature remains neutral with regard to jurisdictional claims in published maps and institutional affiliations.

\section{Submit your manuscript to a SpringerOpen ${ }^{\circ}$ journal and benefit from:}

- Convenient online submission

- Rigorous peer review

- Open access: articles freely available online

- High visibility within the field

- Retaining the copyright to your article

Submit your next manuscript at $\boldsymbol{\nabla}$ springeropen.com 